\title{
PENGARUH AKUNTABILITAS, TRANSPARANSI, DAN KUALITAS PELAYANAN TERHADAP MINAT MUZAKI MEMBAYAR ZAKAT (STUDI PADA LAZ SURABAYA)'
}

\author{
Nahdliatul Amalia \\ Departemen Ekonomi Syariah - Fakultas Ekonomi dan Bisnis - Universitas Airlangga \\ Email: anahdliatul@gmail.com \\ Tika Widiastuti \\ Departemen Ekonomi Syariah - Fakultas Ekonomi dan Bisnis - Universitas Airlangga \\ Email: tika.widiastuti@feb.unair.ac.id
}

\begin{abstract}
:
This study aims to determine the effect of accountability, transparency, and service quality on the interest of muzaki (study at zakat institutionsSurabaya). This study uses a quantitative approach with multiple linear regression analysis. The population in this study is all muzaki registered at zakat institutions in Surabaya. The sampling technique using convenience sampling. This study uses 6 (six) zakat institutions that have been selected by taking a sample of 120 muzaki. Primary data collection in this study used a questionnaire. Based on the results of the study show that accountability, transparency, and service qualitypartially have a positive and significant effect on the interest of muzaki to paying zakat. Accountability, transparency, and service qualitysimultaneously have a positive and significant effect on the interest of muzaki to paying zakat.
\end{abstract}

Keywords: Accountability, Transparency, Service Quality, Interest, Zakat, Zakat Institution.

\section{PENDAHULUAN}

\section{Latar Belakang}

Kemiskinan merupakan salah satu masalah yang sulit dihadapi dan juga sangat krusial dibanding masalahmasalah lainnya.Masalah ini menjadi penyakit yang selalu ada di setiap negara, tidak terkecuali Indonesia. Kompleksitas dari masalah tersebut tidak hanya menyangkut kemiskinan itu sendiri melainkan juga implikasinya yang menyangkut ke seluruh aspek kehidupan, seperti tingkat kesehatan, sarana dan prasarana pendidikan, korupsi yang semakin meningkat, pengangguran dan pemutusan hubungan kerja yang semakin bertambah, dan dampak yang lebih besar adalah terabaikannya
kesejahteraan umat atau masyarakat. Permasalahan

kemiskinan bukanlah hal yang mudah untuk diselesaikan, karena kemiskinan adalah bukti kekuasaan Allah bahwa dengan kemiskinan Allah ingin mengetahui sejauh mana kepedulian hamba-Nya yang diberi harta untuk dapat berbagi dengan yang berkekurangan. Islam menekankan adanya hubungan saling tolong menolong di dalam lingkungan sosial umatnya. Bahkan Islam menggambarkan umat muslim sebagai suatu batang tubuh yang semua anggota dan bagiannya berkaitan dengan bagian yang lain.

Secara demografik mayoritas penduduk Indonesia adalah beragama

\footnotetext{
${ }^{1}$ Jurnal ini merupakan bagian dari skripsi Nahdliatul Amalia, NIM: 041511433082, yang diuji pada tanggal 25 Juni 2019.
} 
Islam.hal ini mengindikasikan adanya potensi zakat yang besar di Indonesia. Dengan adanya zakat mampu mensejahterakan masyarakat dan tidak menutup kemungkinan tingkat kemiskinan masyarakat di Indonesia akan berkurang. Hal ini dapat tercapai apabila masyarakat itu sendiri memiliki kesadaran untuk membayar zakat.Zakat itu sendiri merupakan salah satu dari rukun Islam.

Di Indonesia Organisasi Pengelolaan Zakat (OPZ) di bagi menjadi dua institusi yakni, pertama Badan Amil Zakat (BAZ) yaitu badan pengelola zakat yang dibentuk oleh pemerintah dan didirikan atas usul Kementrian Agama dan disetujui oleh Presiden. Kedua, Lembaga Amil Zakat (LAZ) yaitu lembaga pengelola zakat yang dibentuk oleh swasta atau diluar pemerintah sesuai dengan UndangUndang No. 38 tahun 1999 tentang Pengelolaan Zakat Bab III pasal 6 dan pasal 7.

Dengan adanya BAZ maupun LAZ diharapkan mampu menghimpun dan menyalurkan dana zakat secara optimal. Namun fenomena yang terjadi saat ini potensi penerimaan zakat yang ada tidak sesuai dengan realisasi dana zakat yang diterima.

Permasalahan berikutnya adalah belum tercapainya potensi penerimaan zakat di Indonesia dikarenakan masih banyaknya para muzaki yang tidak menyalurkan dana zakatnya pada organisasi pengelolaan zakat yang ada. Karena kurangnya minat dan kepercayaan para muzaki terhadap organisasi tersebut dan lebih memilih untuk menyalurkan dana zakatnya langsung kepada yang berhak atau 8 asnaf. Penyebab kurangnya minat dan kepercayaan muzaki pada organisasi pengelolaan zakat baik itu Badan Amil Zakat maupun Lembaga Amil Zakat adalah karena kurangnya transparansi dan akuntabilitas pada laporan kevangan yang disajikan serta kurangnya kualitas pelayanan yang diberikan karyawan LAZ terhadap para muzaki.

$$
\text { Selain menuntut adanya }
$$

pelaksanaan transparansi dan akuntabilitas publik,masyarakat juga mempermasalahkan pelayanan yang diberikan oleh LAZ.Kenyataan yang ada saat ini, tidak sedikit lembaga zakat yang memberikan pelayanannya secara tidak maksimal kepada muzaki atau masyarakat. Lokasi lembaga zakat yang sulit dijangkau merupakan salah satu alasan muzaki tidak menyalurkan dana zakatnya pada LAZ dan lebih memilih untuk memberikannya langsung kepada yang berhak. Masyarakat cenderung ingin melakukan segala hal dengan cara yang mudah tanpa harus melakukan banyak usaha untuk mendapatkan apa yang diinginkan. Oleh karena itu, hal ini merupakan tanggung jawab pihak internal lembaga zakat untuk memenuhi keinginan dan memberikan kemudahan bagi para muzaki dalam membayarkan dana zakatnya pada LAZ. 
Dengan adanya permasalahan yang telah dijelaskan, maka sebaiknya perlu dilakukan adanya perbaikan dalam bentuk pelayanannya karena hal tersebut merupakan tanggung jawab LAZ itu sendiri, agar dapat mempermudah muzaki untuk menyalurkan dana zakatnya. Dengan memiliki pelayanan yang berkualitas maka tidak diragukan lagi kredibilitas LAZ tersebut, maka masyarakat akan semakin percaya untuk mengamanahkan dananya dan secara tidak langsung dapat menarik minat muzaki untuk membayar zakat pada LAZ tersebut. Oleh karena itu, akuntabilitas, transparansi, dan kualitas pelayanan sangat penting untuk mempengaruhi minat masyarakat dalam membayar zakat pada lembaga amil zakat.

Alasan peneliti memilih melakukan penelitian pada LAZ di Surabaya adalah karena ingin mengetahui apakah terdapat pengaruh akuntabilitas, transparansi dan kualitas pelayanan terhadap minat muzaki membayar zakat pada LAZ di Surabaya.

\section{Rumusan Masalah}

Berdasarkan uraian latar belakang di atas, maka permasalahan dalam penelitian ini dapat dirumuskan sebagai berikut :

1. Apakah secara simultan (bersamasama) variabel akuntabilitas, transparansi, dan kualitas pelayanan berpengaruh terhadap minat muzaki membayar zakat pada LAZ di Surabaya?
2. Apakah secara parsial (sendiri-sendiri) variabel akuntabilitas, transparansi, dan kualitas pelayanan berpengaruh terhadap minat muzaki membayar zakat pada LAZ di Surabaya?

\section{Tujuan Penelitian}

1. Untuk mengetahui pengaruh secara simultan variabel akuntabilitas, transparansi, dan kualitas pelayanan terhadap minat muzaki membayar zakat pada LAZ di Surabaya.

2. Untuk mengetahui pengaruh secara parsial variabel akuntabilitas, transparansi, dan kualitas pelayanan terhadap minat muzaki membayar zakat pada LAZ di Surabaya.

\section{TINJAUAN PUSTAKA}

\section{Konsep Akuntabilitas}

Menurut Ar Rahman (2003: 46), bahwa dalam Islam, akuntabilitas berarti pertanggungjawaban manusia kepada Allah SWT atas apa yang telah dilakukan.

Dalam pandangan Islam, akuntabilitas bisa dikatakan sebagai bentuk pertanggungjawaban seorang manusia sebagai khalifah di bumi kepada Allah SWT, karena segala sesuatu yang dititipkan Allah SWT kepada manusia merupakan amanah dan segala yang dikerjakan atau diperbuat manusia harus dipertanggungjawabkan di akhirat kelak. Seperti firman Allah dalam Al-Qur'an Surat Al-Mudassir ayat 38:

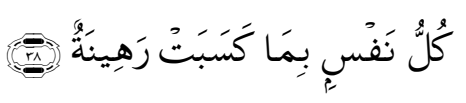

Artinya: "Tiap-tiap diri bertanggung jawab atas apa yang telah diperbuatnya" 
Amanah harus disampaikan kepada yang berhak menerimanya. Begitu pula penerima amanah, juga harus bersikap adil dan menyampaikan kebenaran/tidak ada yang ditutup-tutupi. Akuntabilitas harus diikuti suatu pengendalian yang baik sesuai dengan komitmen yang telah dibuat antara pemberi amanah dengan penerima amanah.Sebagai bentuk pelaksanaan amanah zakat dilaksanakan sesuai syariat Islam, zakat disalurkan kepada 8 asnaf sebagaimana diterangkan dalam AlQur'an.

Dengan demikian akuntabilitas adalah bentuk pertanggungjawaban dari pemegang amanah dalam hal ini adalah lembaga zakat kepada pemberi amanah (muzaki). Jika prinsip akuntabilitas ini dapat diterapkan maka akan memberikan dampak yang baik bagi muzaki terhadap lembaga dan tidak menutup kemungkinan tingkat kepercayaan sekaligus minat para muzaki akan meningkat, dan mempercayakan dana zakatnya pada LAZ tersebut.

\section{Konsep Transparansi}

Menurut Tapanjeh (2009:10), transparansi dalam perspektif Islam adalah:

1. Organisasi bersifat terbuka kepada muzakki. Seluruh fakta yang terkait aktivitas pengelolaan zakat termasuk informasi keuangan harus mudah diakses oleh pihak yang berkepentingan terhadap informasi tersebut.
2. Informasi harus diungkapkan secara jujur, lengkap dan meliputi segala hal yang terkait dengan informasi yang diberikan.

3. Pemberian informasi juga perlu dilakukan secara adil kepada semua pihak yang membutuhkan informasi.

Dari konsep transparansi di atas, dapat disimpulkan bahwa dalam Islam, transparansi erat kaitannya dengan kejujuran.Ketika menyampaikan informasi, pemberi informasi harus bersikap jujur sehingga tidak ada satu pun hal yang luput dari pengetahuan penerima informasi termasuk harus mengkomunikasikan segala kebijakan yang mereka lakukan kepada pemberi amanah dalam hal ini adalah masyarakat atau muzaki. Sehingga masyarakat akan lebih selektif, dan menjadikan pilihan utama untuk mendonasikan Zakat, Infaq, Shodagoh (ZIS), serta berdampak meningkatnya minat masyarakat untuk menentukan sikap minatnya memilih lembaga yang transparan.

Membangun tranparansi dalam pengelolaan ZIS akan menciptakan hubungan yang baik antara lembaga dan masyarakat. Karena tidak hanya melibatkan pihak internal organisasi (lembaga ZIS) namun juga melibatkan pihak eksternal lembaga yaitu masyarakat secara luas.Hal ini sebaiknya dijadikan patokan oleh lembaga untuk beroperasi serta mengurangi rasa curiga atau ketidakpercayaan masyarakat terhadap pengelolaan ZIS yang ada di lembaga. 


\section{Konsep Kualitas Pelayanan}

Kualitas pelayanan menurut Sangadji dan Sopiah, (2013:100) adalah sebagai tingkat keunggulan yang diharapkan dan pengendalian atas tingkat keunggulan tersebut untuk memenuhi keinginan pelanggan.

Menurut Parasuraman dalam Sangadji dan Sopiah (2013:100-101) tentang mengevaluasi jasa yang bersifat Intangible, konsumen umumnya menggunakan beberapa dimensi sebagai berikut:

1. Bukti Langsung (Tangible). Bukti langsung meliputi fasilitas fisik, perlengkapan, pegawai, dan sarana komunikasi.

2. Kehandalan (Reliability). Kehandalan yakni kemampuan memberikan pelayanan yang dijanjikan dengan segera, akurat, dan memuaskan.

3. Daya Tanggap (Responsiveness). Tanggapan yaitu keinginan para staf dan karyawan untuk membantu para pelanggan dan memberikan pelayanan dengan tanggap.

4. Jaminan (Assurance). Jaminan menyangkut pengetahuan, kemampuan, kesopanan, dan sifat dapat dipercaya yang dimiliki para staf, bebas dari bahaya, risiko, atau keraguan.

5. Empati (Emphaty). Empati meliputi kemudahan dalam melakukan hubungan, komunikasi yang baik, perhatian pribadi, dan memahami kebutuhan para pelanggan.
Adapun prinsip-prinsip pelayanan dalam Islam (Hafidhuddin dan Hendri, 2003:56 dalam Lestari, 2013:34-35) yaitu:

1. Shiddia

2. Kreatif, berani, dan percaya diri

3. Amanah dan Fatonah

4. Tabliq

5. Istiqamah

Setiap institusi, perusahaan, atau suatu lembaga sekalipun pasti akan terus memperhatikan pelayanannya kepada pelanggan. Karena hal tersebut sangatlah penting untuk dijaga dan terus diperbaiki yaitu dengan cara terus berusaha memberikan pelayanan yang terbaik sesuai dengan keinginan pelanggan, maka akan berpengaruh dalam menarik minat para pelanggan. Terutama dalam hal ini adalah lembaga zakat, karena dengan memberikan pelayanan yang terbaik maupun terus menjaga kualitas pelayanannya, akan membuat muzaki percaya untuk mengamanahkan dana zakatnya dan secara tidak langsung menarik minat muzaki dalam membayar zakat pada LAZ tersebut.

\section{Konsep Minat Muzaki}

Menurut Jaelani (2006:66) minat merupakan suatu kecenderungan hati terhadap sesuatu yang timbul dari dalam diri seseorang apabila dari sesuatu yang diminati itu bermanfaat, bisa dirasakan, dialami secara nyata, dan bila pihak luar bisa mendorong kearah itu, untuk memberikan perhatian dan bertindak terhadap orang, aktivitas, atau situasi yang menjadi obyek dari minat tersebut 
dengan disertai perasaan senang. Dapat dikatakan bahwa minat merupakan suatu bentuk dorongan yang kuat oleh seseorang untuk melakukan segala sesuatu dalam mewujudkan tujuan yang ingin dicapai.

Menurut Lucas dan Britt (2011:1516), aspek-aspek yang terdapat dalam minat antara lain:

1. Ketertarikan (Interest) yang menunjukkan adanya pemusatan perhatian dan perasaan senang.

2. Keinginan (Desire) ditunjukkan dengan adanya dorongan untuk ingin memiliki.

3. Keyakinan (Conviction) ditunjukkan dengan adanya perasaan percaya diri individu terhadap kualitas, daya guna, dan keuntungan dari produk yang akan dibeli.

Dalam Al-Qur'an juga terdapat ayat yang berkaitan dengan minat, yaitu dalam Al-Qur'an surat Al-Alaq ayat 3-5. Minat disini adalah perintah Allah SWT kepada kita sebagai manusia untuk membaca.Perintah membaca disini bukan hanya sekedar membaca buku atau secara tekstual, namun dalam segala bentuk aspek. Termasuk membaca cakrawala dunia yang merupakan bentuk dari kebesaran-Nya, serta membaca potensi yang kita miliki agar kita dapat memahami apa minat kita sebenarnya dalam kehidupan ini.

\section{Konsep Zakat}

Secara etimologis (bahasa), zakat berasal dari bahasa Arab "zaka" yang berarti berkah, tumbuh, bersih, baik, dan bertambah. Sedangkan secara terminologis (istilah) setiap ulama memiliki pandangan tersendiri mengenai pengertian zakat, akan tetapi pada dasarnya sama dimana zakat merupakan harta dengan persyaratan tertentu, yang Allah mewajibkan kepada pemiliknya, untuk diserahkan kepada yang berhak menerimanya, dengan persyaratan tertentu pula (Hafidudin, 2002:30).

Terdapat dua jenis zakat yaitu zakat fitrah dan zakat harta (maal) (Sri Nurhayati dan Wasilah, 2009:25). Zakat fitrah adalah zakat yang diwajibkan kepada umat muslim pada bulan Ramadhan, tepatnya pada saat matahari terbenam di akhir bulan Ramadhan dan lebih utama dibayarkan sebelum shalat Idul Fitri. Sedangkan zakat maal merupakan zakat atas kekayaan yang dapat dibayarkan kapan saja asalkan objek zakat telah memenuhi syarat. Adapun delapan kelompok (asnaf) orang yang dinyatakan berhak menerima zakat (Mustahik).Delapan asnaf itu adalah Fakir, Miskin, Muallaf, Riqab, Ghorim, Sabilillah, Ibnu Sabil.

\section{Lembaga Amil Zakat}

Pengertian lembaga amil zakat adalah intitusi pengelolaan zakat yang sepenuhnya dibentuk atas prakarsa masyarakat dan oleh masyarakat yang bergerak dibidang da'wah, pendidikan, sosial dan kemaslahatan umat Islam. Lembaga amil zakat ini dikukuhkan, dibina dan dilindungi pemerintah. Dalam melaksanakan tugasnya LAZ memberikan 
laporan kepada pemerintah sesuai dengan tingkatannya (pasal 31 KMA).

Fungsi dan peran lembaga amil zakat (LAZ) menurut Permono (2005:362) adalah:

1) Lembaga amil zakat menjamin terlaksananya Syariat Islam, karena pelaksanaan pengumpulan hingga pendistribusian Zakat, Infaq, Shodaqoh (ZIS) harus selalu dilakukan pengawasan.

2) Pengumpulan ZIS melalui LAZ diharapkan dapat merata dalam pendistribusiannya.

3) Pengumpulan ZIS melalui LAZ lebih mulia, karena muzaki tidak perlu bertatap muka langsung dengan pihak mustahik sehingga dapat menjaga harkat dan martabat kedua belah pihak.

4) Zakat, Infaq dan Shodaqoh lebih terarah pada 8 asnaf dan tidak saja dapat disalurkan melalui individu tertentu tetapi juga dapat melalui Lembaga yang dikelola secara lebih produktif.

\section{Hubungan Antar Variabel}

1. Akuntabilitas sangat penting kaitannya dengan minat muzaki untuk membayar zakat. Karena dalam menarik minat masyarakat atau muzaki untuk menyalurkan dana zakatnya, mereka juga melihat laporan kevangan yang disusun oleh lembaga amil tersebut. Hal ini merupakan hal yang penting untuk menentukan minat para muzaki yang ingin menyalurkan dana zakatnya pada LAZ tersebut atau tidak. Apabila LAZ mampu memberikan kemudahan bagi para muzaki dalam mengakses laporan keuangannya, maka akan semakin meningkatnya kepercayaan masyarakat dalam menyalurkan dana zakatnya pada LAZ yang dituju. memberikan laporan pertanggungjawaban, menyajikan, dan mengungkapkan segala aktivitasnya dan kegiatan operasionalnya secara rutin sebagai bentuk tanggung jawab kepada pihak pemberi amanah maka kepercayaan para muzaki juga akan semakin meningkat untuk menyalurkan dananya pada LAZ

2. Transparansi erat kaitannya dengan kejujuran. Dalam menyampaikan informasi, pemberi informasi harus bersikap jujur sehingga tidak ada satu pun hal yang luput dari pengetahuan penerima informasi dalam hal ini adalah masyarakat atau muzaki. Sehingga masyarakat akan lebih selektif, dan menjadikan pilihan utama untuk mendonasikan ZIS serta berdampak meningkatnya minat masyarakat untuk menentukan sikap minatnya memilih lembaga yang transparan. Jika suatu lembaga transparan dalam mempublikasikan laporan kevangannya maupun kegiatan operasionalnya kepada masyarakat maka akan meningkatkan minat maupun kepercayaan 
muzakidan memilih menyalurkan dana zakatnya pada Lembaga yang dituju.

3. setiap institusi, perusahaan, atau suatu lembaga sekalipun pasti akan terus memperhatikan pelayanannya kepada pelanggan. karena hal tersebut sangatlah penting untuk dijaga dan terus diperbaiki yaitu dengan cara terus berusaha memberikan pelayanan yang terbaik, maka akan berpengaruh dalam menarik minat para pelanggan. Terutama dalam hal ini adalah lembaga zakat, karena dengan memberikan pelayanan yang terbaik dan terus menjaga kualitas pelayanannya, akan menarik minat masyarakat maupun muzakidalam menyalurkan dana zakatnya pada LAZ tersebut.

\section{Model Analisis}

Model analisis yang digunakan dalam penelitian ini adalah analisis regresi linear berganda yang menggunakan data cross section. Model analisis dalam penelitian ini dapat digambarkan sebagai berikut:

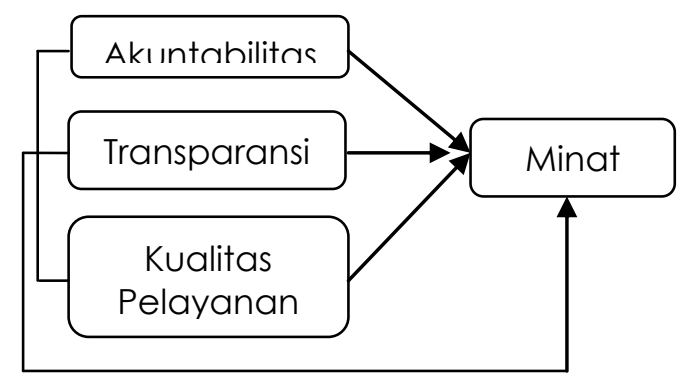

Gambar 1. Model Analisis
1. Variabel akuntabilitas, transparansi, dan kualitas pelayanan secara simultan (bersama-sama) memiliki pengaruh signifikan terhadap minat muzaki membayar zakat pada lembaga amil zakat di Surabaya.

2. Variabel akuntabilitas, transparansi, dan kualitas pelayanan secara parsial (sendiri-sendiri) memiliki pengaruh signifikan terhadap minat muzaki membayar zakat pada lembaga amil zakat di Surabaya.

\section{METODE PENELITIAN}

\section{Pendekatan penelitian}

Penelitian ini menggunakan pendekatan kuantitatif, dimana terdapat variabel-variabel yang akan dijelaskan dan ditelaah hubungannya.

\section{Identifikasi Variabel}

Variabel yang digunakan dalam penelitian ini dibedakan menjadi 2 jenis, yaituvariabel dependen dan variabel independen.Variabel dependen adalah variabel yang dipengaruhi atau yang menjadi akibat karena adanya variabel bebas.Variabel dependen dalam penelitian ini adalah Minat muzaki membayar zakat.Sedangkan variabel independen adalah variabel yang mempengaruhi atau yang menjadi sebab timbulnya variabel dependen.Variabel independen dalam penelitian ini terdiri dari Akuntabilitas, Transparansi dan Kualitas pelayanan.

\section{Definisi Operasional}

1. Akuntabilitas 
Akuntabilitas dapat dipahami sebagai suatu kewajiban pemegang amanah (agent) untuk memberikan pertanggungjawaban, menyajikan dan melaporkan segala aktivitas dan kegiatan yang menjadi tanggungjawabnya kepada pihak pemberi amanah (principal) yang memiliki hak dan kewenangan untuk meminta pertanggungjawaban.

2. Transparansi

Transparansi adalah kegiatan pembangunan yang harus dikelola dengan setransparan mungkin bagi masyarakat, donatur, dan organisasi yang bersangkutan, yang harus diberi wewenang berupa kemudahan untuk mendapatkan informasi yang terkait dengan kebijakan serta kegiatan pembangunan dalam pengelolaan organisasi.

3. Kualitas Pelayanan

Kualitas pelayanan adalah hasil dari suatu proses evaluasi di mana pelanggan membandingkan persepsi mereka terhadap pelayanan dan hasilnya, dengan apa yang mereka harapkan.

4. Minat

Minat merupakan suatu bentuk dorongan yang kuat oleh seseorang untuk melakukan segala sesuatu dalam mewujudkan tujuan yang ingin dicapai.

\section{Penentuan Populasi dan Sampel}

Populasi dalam penelitian ini adalah seluruh muzaki (funder) yang terdaftar di LAZ Surabaya. Data yang diperoleh dari Badan Amil Zakat Nasional Jawa Timur dan beberapa Lembaga Amil Zakat di Surabaya.

Teknik pengambilan sampel yang digunakan dalam penelitian ini adalah teknik nonprobabilitas sampling yaitu metode pemiliham sampel dimana anggota populasi tidak mempunyai peluang yang sama untuk dipilih menjadi sampel. Dengan cara sampel menggunakan metode convience sampling yaitu metode pengambilan sampel yang didasarkan pada pemilihan anggota populasi yang mudah diakses untuk memperoleh jawaban atau informasi. Dalam penelitian ini sampel yang diambil sebanyak 120 responden yang diperoleh dari muzaki di 6 (enam) LAZ di Surabaya.

\section{Jenis dan Sumber Data}

Jenis dan sumber data pada penelitian ini adalah sebagai berikut:

a. Data primer,yaitu berupa hasil pembagian kuesioner terhadap responden, dalam hal ini adalah muzaki yang dipilih secara acak oleh peneliti..

b. Data Sekunder, yaituberupa bukubuku, berita online, jurnal dan artikel yang relevan dengan akuntabilitas, transparansi serta kualitas pelayanan, juga dokumen yang berasal dari OPZ yang dapat diakses di web organisasi.

\section{Metode Pengumpulan Data}

Metode pengumpulan data pada penelitian ini adalah sebagai berikut: 
a. Kuesioner, yaitu dilakukan dengan menyebarkan daftar pertanyaan kepada para muzaki. Kuesioner dibuat dalam bentuk pernyataan dengan lima butir opsi jawaban untuk setiap pertanyaan. Skala pengukuran yang digunakan adalah skala pengukuran likert dengan lima tingkatan jawaban. Lima tingkatan jawaban akan dijelaskan dalam Tabel 1 sebagai berikut:

Tabel 1. Tingkatan Jawaban

\begin{tabular}{|c|c|}
\hline Jawaban & Skor \\
\hline Sangat setuju & 5 \\
\hline Setuju & 4 \\
\hline Netral/Ragu-ragu & 3 \\
\hline Tidak setuju & 2 \\
\hline Sangat tidak setuju & 1 \\
\hline
\end{tabular}

Sumber: Sutrisno Hadi, 1991

b. Studi dokumentasi, dilakukan melalui pengumpulan data melalui buku (bersifat teoritis), literature, penelitian sebelumnya, atau website yang berhubungan dengan populasi penelitian dan dokumen organisasi berupa annual report lembaga amil zakat di Surabaya.

c. Data Cross Section, yaitu data yang terkumpul pada suatu waktu tertentu untuk memberikan gambaran perkembangan keadaan atau kegiatan pada waktu itu.

\section{Teknik Analisis Data}

a. Uji Kualitas Data
Uji kualitas data dalam penelitian ini meliputi uji validitas dan uji reliabilitas.Uji validitas dilakukan pada setiap butir pertanyaan dengan membandingkan hasil r-hitung dengan r-tabel.Apabila r-hitung lebih besar dari r-tabel, maka data dikatakan valid.Uji reliabilitas dalam penelitian ini adalah dengan menghitung Cronbach Alpha. Suatu variabel dikatakan reliable jika hasil uji reliabilitasnya memiliki nilai Cronbach Alpha $>0,60$.

b. Uji Asumsi Klasik

Pengujian asumsi klasik meliputi uji normalitas, uji multikolinearitas dan uji heteroskedastisitas.Uji normalitas menggunakan uji Kolmogrov-Smirnov. Uji heterokedastisitas dengan menggunakan grafik scatterplot. Uji multikolinearitas dilakukan dengan melihat nilai tolerance serta Variance Inflation Factor (VIF).

c. Uji Hipotesis

Uji hipotesis dilakukan dengan menggunakan metode regresi linear berganda, koefisien determinasi, uji parsial $(t)$ dan uji simultan (F)

\section{PEMBAHASAN}

\section{Hasil Uji Kualitas Data}

a. Hasil Uji Validitas

Hasil uji validitas menunjukkan bahwa setiap pertanyaan dari variabel akuntabilitas, transparansi, kualitas pelayanan, dan minat muzaki membayar zakat dinyatakan valid. Hal 
tersebut dikarenakan nilai r-hitung lebih besar dari nilai r-tabel $(0,1793)$

b. Hasil Uji Reliabilitas

Hasil uji reliabilitas menunjukkan bahwa setiap variabel yang digunakan dalam penelitian ini dinyatakan reliable. Hal tersebut dapat dilihat dari hasil nilai Cronbach Alpha pada variabel akuntabilitas sebesar 0,903, variabel transparansi sebesar 0,690, variabel kualitas pelayanan sebesar 0,878 , dan variabel minat sebesar 0,860. Dimana nilai Cronbach Alpha disemua variabelnya lebih besar dari 0,60

\section{Hasil Uji Asumsi Klasik}

a. Hasil Uji Normalitas

Penelitian ini tidak diberlakukan uji normalitas, karena jumlah sampel yang digunakan sebanyak 120 responden. Apabila sampel moderate-besar, rata-rata sampel diperlakukan berdistribusi normal walaupun sebenarnya tidak normal. Dari uraian di atas dapat disimpulkan bahwa "Jika jumlah sampel untuk setiap populasi adalah besar (lebih dari 40), maka t-test dapat digunakan tanpa perlu memperhatikan normalitas dan data outlier" (Hengky Latan, 2014:147).

b. Hasil Uji Multikolinearitas

Hasil perngujian diperoleh nilai tolerance lebih besar dari 0,1 dan nilai VIF lebih kecil dari 10. Dari hasil tersebut, dapat disimpulkan bahwa tidak terjadi multikolinearitas.
Tabel 2.

Hasil Uji Multikolinearitas

\begin{tabular}{|c|c|c|}
\hline Variabel & Tolerance & VIF \\
\hline Akuntabilitas & 0,288 & 3,472 \\
\hline Transparansi & 0,438 & 2,282 \\
\hline Kualitas Pelayanan & 0,370 & 2,704 \\
\hline
\end{tabular}

Sumber: Diolah Penulis, 2019

c. Hasil Uji Heterokedastisitas

Gambar 2 menunjukkan bahwa titik-titik menyebar secara acak serta tersebar baik di atas maupun di bawah angka 0 pada sumbu Y. Hal ini dapat disimpulkan bahwa tidak terjadi heteroskedastisitas.

Scatterplot

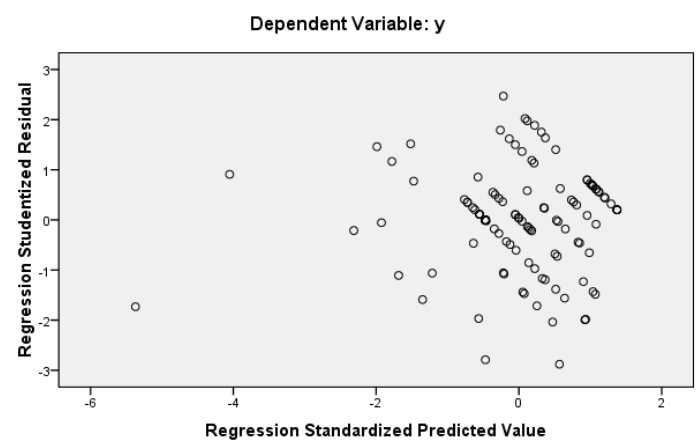

Sumber: Data Diolah Peneliti, 2018

Gambar 2.

Hasil Uji Heterokedastisitas

\section{Hasil Uji Hipotesis}

a. Hasil Analisis Persamaan Regresi Linear Berganda

Berdasarkan hasil dari pengolahan data dengan program SPSSmengenai pengaruh akuntabilitas, transparansi, dan kualitas pelayanan terhadap minat muzaki membayar zakat di LAZ surabaya maka 
hasilnyadiperoleh persamaan regresi sebagai berikut:

$Y=1,174+0,190 X_{1}+0,169 X_{2}+0,421 X_{3}+e$

Keterangan:

$Y \quad:$ Minat

$X_{1} \quad:$ Akuntabilitas

$X_{2} \quad$ : Transparansi

$X_{3} \quad$ : Kualitas pelayanan

e : Error

b. Hasil Koefisien Determinasi $\left(R^{2}\right)$

Hasil koefisien determinasi $\left(R^{2}\right)$ menunjukkan nilai sebesar 0,665 atau $66,5 \%$. Hal ini berarti variabel minat muzakimembayar zakat dipengaruhi oleh akuntabilitas, transparansi, dan kualitas pelayanan sebesar $66,5 \%$ sedangkan sisanya $33,5 \%$ dipengaruhi oleh variabel lain diluar model regresi ini.

c. Koefisien Parsial (Uji t)

Pengujian ini pada dasarnya menunjukkan seberapa jauh pengaruh satu variabel independen secara individual dalam menerangkan variasi variabel dependen.Adapun kriteria dalam uji parsial (Uji t):

1) Jika nilai t-hitung $\geq$ t-tabel Ho ditolak, maka ada pengaruh yang signifikan antara variabel independen terhadap variabel dependen.

2) Jika nilai t-hitung $\leq \mathrm{t}$-tabel Ho diterima, maka tidak ada pengaruh yang signifikan antara variabel independen terhadap variabel dependen.

Hasil pengujian dilakukan dengan program SPSSdapat dilihat pada tabel berikut:

Tabel 3.

Hasil Uji $t$

\begin{tabular}{|l|c|}
\hline \multicolumn{1}{|c|}{ Variabel } & Nilai $\boldsymbol{t}$ \\
\hline (Constant) & 1,087 \\
\hline Akuntabilitas & 1,975 \\
\hline Transparansi & 2,322 \\
\hline Kualitas Pelayanan & 5,712 \\
\hline
\end{tabular}

Sumber: Data Diolah Peneliti, 2019

Berdasarkan hasil pengujian di atas dapat disimpulkan bahwa secara parsial variabel akuntabilitas, transparansi, dan kualitas pelayanan berpengaruh positif dan signifikan terhadap minat muzaki membayar zakat.

d. Uji Koefisien Simultan (Uji F)

Uji $F$ dilakukan dengan tujuan untuk mengetahui seberapa jauh variabel independen atau bebas secara bersamasama dapat mempengaruhi variabel dependen atau terikat.Ketentuan penerimaan atau penolakan hipotesis adalah sebagai berikut:

a) Jika signifikan $F>0,05$ maka $\mathrm{Ho}$ diterima dan $\mathrm{Ha}$ ditolak (koefisien regresi tidak signifikan). Ini berarti bahwa secara simultan ketiga variabel independen tidak mempunyai pengaruh yang signifikan terhadap variabel dependen.

b) Jika signifikan $F \leq 0,05$ maka Ho ditolak dan $\mathrm{Ha}$ diterima (koefisien regresi signifikan). Ini berarti bahwa secara simultan ketiga variabel independen mempunyai pengaruh yang signifikan terhadap variabel dependen.

Hasil uji $F$ mengenai pengaruh akuntabilitas, transparansi, dan kualitas pelayananterhadap minat muzaki 
membayar zakat, dapat dilihat pada tabel berikut:

Tabel 4.

Hasil Uji $F$

\begin{tabular}{|c|c|}
\hline Nilai $\boldsymbol{F}$ & Sig. \\
\hline 76,843 & 0,000 \\
\hline
\end{tabular}

Sumber: Diolah Peneliti, 2019

Berdasarkan hasil pengujian di atas, nilai dari F-hitung adalah 76,843 dengan nilai signifikan sebesar 0,000 . Nilai signifikan dari hasil tersebut lebih kecil dari 0,05 . Oleh karena itu dapat disimpulkan bahwa terdapat pengaruh akuntabilitas, transparansi, dan kualitas pelayanan secara simultan (bersama-sama) terhadap minat muzaki membayar zakat pada LAZ di Surabaya.

Pembahasan Pengaruh Akuntabilitas, Transparansi, dan Kualitas Pelayanan Secara Parsial Terhadap Minat Muzaki Membayar Zakat

1. Hasil penelitian menunjukkan bahwa akuntabilitas memiliki pengaruh positif dan signifikan terhadap minat muzaki membayar zakat. Hal ini dikarenakan nilai t-hitung sebesar 1,975 yang artinya $\mathrm{H}_{0}$ ditolak karena nilai t-hitung lebih besar dari t-tabel atau (1,975 > $1,96)$.

2. Hasil penelitian menunjukkan bahwa transparansi memiliki pengaruh positif dan signifikan terhadap minat muzaki membayar zakat. Hal ini dikarenakan nilai t-hitung sebesar 2,322 yang artinya $\mathrm{HO}$ ditolak karena nilai t-hitung lebih besar dari t-tabel atau (2,322 > 1,96).
3. Hasil penelitian menunjukkan bahwa kualitas pelayanan memiliki pengaruh positif dan signifikan terhadap minat muzaki membayar zakat. Hal ini dikarenakan nilai t-hitung sebesar 5,712 yang artinya $\mathrm{HO}$ ditolak karena nilai t-hitung lebih besar dari t-tabel atau $(5,712>1,96)$.

4. Berdasarkan hasil uji $F$ menunjukkan bahwa terdapat pengaruh akuntabilitas, transparansi, dan kualitas pelayanan secara simultan terhadap minat muzaki membayar zakat. Hal ini dapat dilihat dari nilai F-hitung sebesar 76,843 dengan nilai signifikansi 0,000. Nilai signifikansi dari hasil tersebut lebih kecil dari 0,05. Dapat disimpulkan bahwa akuntabilitas, transparansi, dan kualitas pelayanan secara simultan (bersama-sama) berpengaruh signifikan terhadap minat muzaki membayar zakat pada LAZ di Surabaya.

\section{v. SIMPULAN}

1. Hasil uji $t$ pada model regresi dalam penelitian ini adalah variabel akuntabilitas, transparansi, dan kualitas pelayanan secara parsial berpengaruh positif dan signifikan terhadap minat muzaki membayar zakat.

2. Hasil uji $F$ pada model regresi dalam penelitian ini adalah variabel akuntabilitas, transparansi, dan kualitas pelayanan secara simultan berpengaruh positif dan signifikan 
terhadap minat muzaki membayar zakat.

\section{DAFTAR PUSTAKA}

Ar Rahman, Muhammad .A.M. (2003).1001 masalah zakat dan solusinya. Jakarta: Pustaka Cerdas Zakat.

Hadi, Sutrisno. (1991). Analisis Butir Untuk Instrumen Angket, Tes, dan Skala Nilai. Yogyakarta: FP UGM.

Hafidhuddin, Didin. (2002). Zakat Dalam Perekonomian Modern. Jakarta: Gema Insani Press.

Jaelani, A.F..(2006). Membuka Pintu Rezeki.Depok: Gema Insani.

Lucas, D.B \& Britt, S.H. 2003.Advertising Psychology and Research. New York: Mc Graw-Hill.
Nurhayati, Sri dan Wasilah. (2009). Akuntansi Syariah di Indonesia.Edisi 2. Jakarta: Salemba Empat.

Permono, Sjechul Hadi. (2005). Formula Zakat Menuju Kesejahteraan Sosial. Surabaya: CV. Aulia Surabaya.

Sangadji, Etta Mamang dan Sopiah.(2013). Perilaku Konsumen. Yogyakarta: CV ANDI OFFSET.

Tapanje, A.M.A. (2009). Corporate Governance from The Islamic Perspective: A Comparative Analysis With OECD Principles, Critical Perspectives On Accounting. Vol 20.

Undang-undang Nomor 38 Tahun 1999 Tentang Pengelolaan Zakat. 